\section{Water and Nutrient Uptake Efficiency in Containerized Production of Fern Leaf Lavender Irrigated with Saline Water}

\author{
Pedro García-Caparrós, Alfonso Llanderal, and María Teresa Lao ${ }^{1}$
}

ADDITIONAL INDEX wORDs. Lavandula multifida, leachate, native species, ornamental plants, sodium chloride

SUMMARY. The scarcity of water in the Mediterranean area has frequently led to the use of saline water for irrigation. Container grown ornamental production has relatively high rates of water and nutrient loss from fertigation. A better understanding of water and nutrient use efficiency with water that has elevated levels of saline could reduce runoff water and its environmental impact. Fern leaf lavender (Lavandula multifida) plants were grown for 8 weeks in plastic containers with a sphagnum peatmoss and perlite substrate $(80: 20$ by volume) to evaluate the effect of saline water $\left[2.0\left(\mathrm{~T}_{1}\right.\right.$ or control $), 4.5\left(\mathrm{~T}_{2}\right)$, or $\left.7.5\left(\mathrm{~T}_{3}\right) \mathrm{dS} \cdot \mathrm{m}^{-1}\right]$ on water and nutrient uptake efficiency. Leachate was collected to determine runoff volume and composition which included nitrate-nitrogen $\left(\mathrm{NO}_{3}{ }^{-} \mathrm{N}\right)$, phosphate-phosphorus $\left(\mathrm{PO}_{4}{ }^{2-}-\mathrm{P}\right)$, and potassium $\left(\mathrm{K}^{+}\right)$concentration. Plant dry weight (DW) and nutrient content were determined in plants at the beginning and at the end of the experiment to establish the nutrient balance. Increasing salinity levels of irrigation water did not significantly reduce either the plant DW or the water use efficiency (WUE). Based on nutrient balance, the increasing salinity $\left(2.0\right.$ to $\left.7.5 \mathrm{dS} \cdot \mathrm{m}^{-1}\right)$ affected the plant nutrient uptake efficiency, which decreased $28 \%$ for $\mathrm{N}$, increased $26 \%$ for $\mathrm{P}$ from the lowest to highest sodium chloride levels; whereas $\mathrm{K}$ did not show a clear trend. Nutrient runoff increased $(28 \% \mathrm{~N}, 9 \% \mathrm{P}$, and $27 \% \mathrm{~K})$ to the environment from the lowest to highest sodium chloride levels.

$\mathrm{T}$ The worldwide production value of containerized plants has increased in recent years due to the great consumption of these types of plant in gardens and landscapes (Lütken et al., 2012). There is however, a decrease in production in some areas of the world, in part, due to increased salinity in both soil and water (Cassaniti et al., 2013). This is the case for the southeastern coastal areas of Spain where there is high water salinity due to saltwater intrusion into some groundwater aquifers (Daniele et al., 2011).

The production of container plants requires irrigation with high fertilization rates, often multiple times daily, because of container volume limitations and substrate properties, resulting in the contamination of ground and surface water (Chavez et al., 2008). This environmental

\footnotetext{
Agronomy Department of Higher Polytechnic School and Experimental Science College, University of Almeria, Agrifood Campus of International Excellence ceiA3. Ctra. Sacramento s/n, La Cañada de San Urbano, 04120, Almería, Spain

The authors thank Professor Timothy Broschat for his suggestions and English style corrections.

${ }^{1}$ Corresponding author. E-mail: mtlao@ual.es.

doi: 10.21273/HORTTECH03428-16
}

problem is exacerbated with the use of saline water, since the salt accumulation is due to salt in both the irrigation water and fertilizer (Dudley et al., 2008).

The southeastern coast of Spain has a thriving ornamental industry as well as saltwater intrusion, which impacts the water quality that growers use for irrigation, which threatens production in this area. Further investigation is necessary on the effects of different water salinity and nutrient uptake efficiencies and their losses in the production of container plants.

We investigated fern leaf lavender because it is a native Mediterranean species that is frequently used in landscapes due to its ability to adapt to stressful environmental conditions such as salinity (Alvarez et al., 2012). Fern leaf lavender is a small semievergreen perennial shrub native to southeastern Europe and North Africa (Pignatti, 1982) and frequently found in Almería (Dana et al., 2002).

Reviewing previous literature, there is substantial information about the effect of different regimes of irrigation (Pershey and Cregg, 2015; Pinto et al., 2008; Warsaw et al., 2009) or fertilizer supplies (Ristvey et al., 2007; Wilson and Albano, 2011) on nutrient uptake efficiencies and their losses in the production of other containerized plants, but very little is known about the effects of salt stress on water and nutrient uptake efficiencies and their losses in fern leaf lavender grown in containers. Therefore, in this trial, a container experiment with fern leaf lavender was established to determine the effects of different salinity levels of irrigation water on DW, water, and nutrient uptake efficiencies, and their losses.

\section{Materials and methods}

P L A N T M A TER I A A N D EXPERIMENTAL CONDITIONS. The experiment was carried out at the University of Almeria (lat. $36^{\circ} 49^{\prime} \mathrm{N}$, long. $2^{\circ} 24^{\prime} \mathrm{W}$ ). Rooted cuttings of fern leaf lavender were obtained from a local nursery with an average DW of $3.4 \mathrm{~g}$ and transplanted into $1.5-\mathrm{L}$ polyethylene containers (one plant per container) containing peatmoss and perlite 80:20 (by volume). During the 8 weeks of the trial ( 7 May to 1 July 2010), the containers were placed in a $150-\mathrm{m}^{2}$ greenhouse. The microclimatic conditions inside the greenhouse for the experimental period were monitored continuously

\begin{tabular}{llll}
\hline $\begin{array}{l}\text { Units } \\
\text { To convert U.S. to SI, } \\
\text { multiply by }\end{array}$ & U.S. unit & SI unit & $\begin{array}{l}\text { To convert SI to U.S., } \\
\text { multiply by }\end{array}$ \\
\hline 29.5735 & $\mathrm{fl} \mathrm{oz}$ & $\mathrm{mL}$ & 0.0338 \\
0.0929 & $\mathrm{ft}^{2}$ & $\mathrm{~m}^{2}$ & 10.7639 \\
3.7854 & $\mathrm{gal}$ & $\mathrm{L}$ & 0.2642 \\
1 & $\mathrm{micron}(\mathrm{s})$ & $\mu \mathrm{m}$ & 1 \\
1 & $\mu \mathrm{mho} / \mathrm{cm}$ & $\mu \mathrm{S} \cdot \mathrm{cm}^{-1}$ & 1 \\
1 & $\mathrm{mmho} / \mathrm{cm}$ & $\mathrm{dS} \cdot \mathrm{m}^{-1}$ & 1 \\
28.3495 & $\mathrm{oz}$ & $\mathrm{g}$ & 0.0353 \\
28,350 & $\mathrm{oz}$ & $\mathrm{mg}$ & $3.5274 \times 10^{-5}$ \\
7.4892 & $\mathrm{oz} / \mathrm{gal}$ & $\mathrm{g} \cdot \mathrm{L}^{-1}$ & 0.1335 \\
1 & $\mathrm{ppm}$ & $\mathrm{mg} \cdot \mathrm{L}^{-1}$ & 1 \\
$\left({ }^{\circ} \mathrm{F}-32\right) \div 1.8$ & ${ }^{\circ} \mathrm{F}$ & ${ }^{\circ} \mathrm{C}$ & $\left({ }^{\circ} \mathrm{C} \times 1.8\right)+32$ \\
& & & \\
\hline
\end{tabular}


with a data logger $(\mathrm{HOBO}$ model $\mathrm{H}$ 08-004-02; Onset Computer Corp., Bourne, MA). Average maximum/ minimum temperatures were 36/ $18{ }^{\circ} \mathrm{C}$, and average maximum $/ \mathrm{mini}^{-}$ mum of $82 \% / 40 \%$ relative humidity, and an average maximum/minimum of photosynthetically active radiation (PAR) of $235 / 215 \mu \mathrm{mol} \cdot \mathrm{m}^{-2} \cdot \mathrm{s}^{-1}$.

EXPERIMENTAL DESIGN AND TREATMENTS. The experiment consisted of three treatments using different salinities in a standard nutrient solution reported by Jimenez and Caballero (1990) for an adequate growth of ornamental plants in the Mediterranean region. The solution contained (in $\mathrm{mg} \cdot \mathrm{L}^{-1}$ ): 68 phosphates $\left(\mathrm{H}_{2} \mathrm{PO}_{4}^{-}\right), 372$ nitrates $\left(\mathrm{NO}_{3}{ }^{-}\right), 192$ sulfates $\left(\mathrm{SO}_{4}{ }^{2-}\right), 117$ potassium $\left(\mathrm{K}^{+}\right)$, 80 calcium $\left(\mathrm{Ca}^{2+}\right)$, and 34 magnesium $\left(\mathrm{Mg}^{2+}\right)$ amended with different concentrations of sodium chloride $[\mathrm{NaCl}$ (sole salinizing agent)] to achieve electrical conductivity (EC) levels of the irrigation water (EC) of either 2.0 ( $\mathrm{T}_{1}$ or control), $4.5\left(\mathrm{~T}_{2}\right)$ or $7.5\left(\mathrm{~T}_{3}\right)$ $\mathrm{dS} \cdot \mathrm{m}^{-1}$. The standard nutrient solution was derived from tap water $(\mathrm{pH}$ 8.1, EC $0.9 \mathrm{dS} \cdot \mathrm{m}^{-1}, 50 \mathrm{mg} \cdot \mathrm{L}^{-1} \mathrm{Ca}^{2+}$, $34 \mathrm{mg} \cdot \mathrm{L}^{-1} \mathrm{Mg}^{2+}$ ) and phosphoric acid, nitric acid, potassium nitrate, and calcium nitrate. The volume of nutrient solution added manually every day to each container was $70 \mathrm{~mL}$ ( $45 \%$ of the container capacity) for each saline treatment during the experimental growing period. The runoff of each container was collected weekly by placing a plastic collection bucket under each container. The buckets were tightly fitted to the containers to prevent evaporation of runoff between collection events and containers were also elevated to prevent them from sitting in the runoff. The levels of EC were established according to the data reported by Contreras (2014) who established that the minimum and maximum EC values were of 2 and $7.5 \mathrm{dS} \cdot \mathrm{m}^{-1}$ in the aquifers used for irrigation in the southeastern coastal areas of Spain. The experimental design consisted of three salinity treatments, four blocks, and four plants (one plant per container) per block giving a total of 12 plants plus border plants. Border plants (36) were placed around the perimeter of the treatment plants to maintain uniform growing conditions for treatment plants.
MONITORING OF IRRIGATION AND RUNOFF WATER VOLUME AND CHEMICAL COMPOSITION. Four containers per treatment were randomly selected during the experimental growing period to determine the volume of runoff. Runoff was collected weekly and sample aliquots $(25 \mathrm{~mL})$ were filtered through $0.45-\mu \mathrm{m}$ membrane filters and frozen until nutrient analyses were conducted. From each aliquot, $\mathrm{EC}$ and $\mathrm{pH}$ values were determined by conductivity meter (models C66; Milwaukee Instruments, Rocky Mount, NC) and pH meter (model pH52, Milwaukee Instruments); and the concentrations of $\mathrm{NO}_{3}{ }^{-} \mathrm{N}, \mathrm{PO}_{4}{ }^{2-}-\mathrm{P}$, and $\mathrm{K}^{+}$were determined by high-performance liquid chromatography (HPLC) [model 883 Basic IC Plus, anions ion exchange column model Metrosep A SUPP 4, cations ion exchange column model Metrosep C4 100, IC conductivity detector range $\left(0-15,000 \mu \mathrm{S} \cdot \mathrm{cm}^{-1}\right)$; Metrohm, Herisau, Switzerland)] as described by Csáky and MartínezGrau (1998). During the experimental growing period, nutrients applied and runoff per plant (in milligrams) were calculated by multiplying the nutrient concentration in the nutrient solution or runoff by their respective volume. These values were then used to calculate the nutrients runoff per plant in percent (percentages that reflect the fraction of applied nutrient which was leached by the plant during 8 weeks).

Biomass and WUE. At the end of the experiment, the plants of the containers randomly designated for the runoff collection were harvested and the substrate gently washed from the roots. The plants were divided into roots, stems, and leaves and washed with distilled water to be subsequently dried with blotting paper. Roots, stems, and leaves were then oven-dried at $60{ }^{\circ} \mathrm{C}$ until they reached a constant weight to measure the respective DWs. The plant DW was calculated as the sum of leaves, stems, and roots. The WUE (grams DW per liter of water applied) of each treatment was calculated as the difference between plant DW after 8 weeks and the initial plant DW divided by the volume of water applied during the experimental period.

Plant nutrient uptake. The oven-dried samples were ground to a fine powder in a mill (Grindomix
GM 200; Retsch, Haan, Germany) taking care to clean the mill thoroughly between each sample. Each sample was divided in two subsamples. The soluble ionic form of nitrates was quantified through HPLC as described by Csáky and MartínezGrau (1998). Samples were also mineralized with sulfuric acid $\left[\mathrm{H}_{2} \mathrm{SO}_{4}\right.$ $(96 \%)]$ in the presence of $\mathrm{P}$-free hydrogen peroxide $\left[\mathrm{H}_{2} \mathrm{O}_{2}(30 \% \mathrm{w} / \mathrm{v})\right]$ at $300{ }^{\circ} \mathrm{C}$ and used for the determination of organic N (Krom, 1980), total P (Hogue et al., 1970), and $\mathrm{K}^{+}$ (Lachica et al., 1973) concentration. The total $\mathrm{N}$ concentration was calculated as the sum of the organic $\mathrm{N}$ and $\mathrm{NO}_{3}{ }^{-}$concentration. From these determinations and with the DW measured, we calculated the plant nutrient uptake as the difference between final tissue nutrient content after 8 weeks and the initial nutrient content. An initial harvest at the beginning of the experiment gave an average of $75 \mathrm{mg} \mathrm{N}, 9 \mathrm{mg} \mathrm{P}$, and $3 \mathrm{mg} \mathrm{K}$ per plant. These values of nutrient uptake were then used to calculate nutrient uptakes efficiencies (percentages that reflect the fraction of applied nutrient accumulated by plant during the 8 weeks).

Statistical analysis. The experiment was analyzed as a randomized complete block design, and the values obtained for each plant and each variable were considered as independent replicates. The analysis of variance and the least significant difference tests at $P<0.05$ were used to assess the differences between treatments. All statistical analyses were performed using Statgraphics Plus (version 5.1 for Windows; Statpoint Technologies, Warrenton, VA).

\section{Results and discussion}

Biomass AND WUE. Among the treatments, plant DW was not significantly affected by salinity (Table 1 ). These results may be due to the lower levels of salinity applied in this experiment to exhibit differences in plant DW in fern leaf lavender. It is typical to find a reduction of growth and plant DW under saline conditions, which induces water stress, caused by the greater difficulty of water absorption, and ionic stress, related to the sodium ion effect (Munns and Tester, 2008).

Although, the volume of saline irrigation water was the same for each 
treatment during the crop growing period, the volume of water leached per plant increased with increasing $\mathrm{NaCl}$ in the irrigation water because the plants could be salt stressed, and thus had higher leaching rates (Table $1)$. Leachate volumes per plant were 1.6 and 2.2 times higher in $\mathrm{T}_{2}$ and $\mathrm{T}_{3}$; respectively, compared with the control plants $\left(\mathrm{T}_{1}\right)$. These results agree with Hanson et al. (2006) who reported that an increase of salinity in the root zone decreased the water uptake in plants and consequently increased leaching.

The WUE was not significantly affected by salinity because the volume of nutrient solution was the same for each treatment and also because there were no significant differences in growth in plants due to the salt treatments (Table 1). Different results were found by Alvarez and Sánchez-Blanco (2014) who reported a decrease of WUE related with a growth decrease in red bottlebrush (Callistemon citrinus) production in containers irrigated with saline water.

IRRIGATION AND RUNOFF WATER QUALITY. The EC values of the runoff increased compared with the nutrient solution, except for $\mathrm{T}_{1}$ (Table 2 ). The runoff and nutrient solution had similar concentrations of $\mathrm{NO}_{3}{ }^{-}-\mathrm{N}$ and $\mathrm{K}$ in all the treatments and may be due to the plants having these elements in excess, whereas $\mathrm{PO}_{4}{ }^{2-}-\mathrm{P}$ concentrations exhibited differences between runoff and nutrient solutions. The lower concentrations of $\mathrm{PO}_{4}{ }^{2-}-\mathrm{P}$ in runoff with respect to the nutrient solutions may be related with the nutrient demands of this species during the experimental period and also may be bound in the substrate. From an environmental perspective, the average of $\mathrm{NO}_{3}{ }^{-} \mathrm{N}$ concentrations in this experiment $\left(88-93 \mathrm{mg} \cdot \mathrm{L}^{-1}\right)$ exceeded the threshold of $10 \mathrm{mg} \cdot \mathrm{L}^{-1}$ of $\mathrm{NO}_{3}{ }^{-} \mathrm{N}$ for drinking water by about 9-times [U.S. Environmental Protection Agency (USEPA), 2010] and the threshold of $50 \mathrm{mg} \cdot \mathrm{L}^{-1}$ established by European Environmental Agency (2014) by 1.8-times. Likewise, the average of $\mathrm{PO}_{4}{ }^{2-}$-P concentrations $\left(8.4-9.0 \mathrm{mg} \cdot \mathrm{L}^{-1}\right)$ exceeded the threshold of $0.025 \mathrm{mg} \cdot \mathrm{L}^{-1}$ established by USEPA (2010) for drinking water by 360-times. These higher concentrations of nutrients in the runoff may result in undesirable changes in natural ecosystems due to eutrophication (Brady and Weil, 1999; Howarth and Marino, 2006).

Nutrient Balance. Plant nutrient uptake was affected by salinity treatments (Table 3). Plant nitrogen uptake decreased with higher EC, which may be due to $\mathrm{Cl}^{-}$competing for binding sites with nitrogen (Abdelgadir et al., 2005). Plant phosphorus uptake increased with higher EC $\left(4.5\right.$ and $\left.7.5 \mathrm{dS} \cdot \mathrm{m}^{-1}\right)$ compared with the control plants. This increase

Table 1. Influence of salt treatments on plant dry weight, volume of water leached and water use efficiency of fern leaf lavender grown in 1.5-L (0.40 gal) containers containing peatmoss and perlite 80:20 (v/v). Standard nutrient solutions amended with different concentrations of sodium chloride to achieve EC levels of the irrigation water of 2.0 ( $T_{1}$ or control), $4.5\left(\mathrm{~T}_{2}\right)$, or $7.5\left(\mathrm{~T}_{3}\right) \mathrm{dS} \cdot \mathrm{m}^{-1} .^{\mathrm{z}}$

\begin{tabular}{lccc}
\hline Salinity treatments & ${\text { Plant dry wt }\left(\mathrm{g} / \text { plant }^{\mathrm{z}}\right.}^{\mathrm{z}}$ & ${\text { Water leached }\left(\mathrm{L} / \text { plant }^{\mathrm{z}}\right.}$ & ${\text { Water use efficiency }\left(\mathrm{g} \cdot \mathrm{L}^{-1}\right)^{\mathrm{x}}}^{(\text {mean } \pm \mathrm{SD})}$ \\
\hline $\mathrm{T}_{1}\left(2.0 \mathrm{dS} \cdot \mathrm{m}^{-1}\right)$ & $10.21 \pm 1.49 \mathrm{a}^{\mathrm{w}}$ & $0.74 \pm 0.14 \mathrm{c}$ & $1.71 \pm 0.35 \mathrm{a}$ \\
$\mathrm{T}_{2}\left(4.5 \mathrm{dS} \cdot \mathrm{m}^{-1}\right)$ & $9.00 \pm 1.51 \mathrm{a}$ & $1.21 \pm 0.11 \mathrm{~b}$ & $1.43 \pm 0.24 \mathrm{a}$ \\
$\mathrm{T}_{3}\left(7.5 \mathrm{dS} \cdot \mathrm{m}^{-1}\right)$ & $8.50 \pm 1.56 \mathrm{a}$ & $1.60 \pm 0.14 \mathrm{a}$ & $1.28 \pm 0.36 \mathrm{a}$ \\
\hline
\end{tabular}

${ }^{\mathrm{z}} \mathrm{l} \mathrm{dS} \cdot \mathrm{m}^{-1}=1 \mathrm{mmho} / \mathrm{cm}, \mathrm{lg}=0.0353 \mathrm{oz}, \mathrm{l} \mathrm{L}=0.2642 \mathrm{gal}$

yTreatments were applied from 7 May to 1 July 2010 (8 weeks).

'Water use efficiency was calculated as grams increase in plant over study per volume of water applied; $1 \mathrm{~g} \cdot \mathrm{L}^{-1}=0.1335 \mathrm{oz} / \mathrm{gal}$.

${ }^{w}$ Means with the same letters within a column are not significantly different at $P<0.05$ (analysis of variance and least significant difference test).

Table 2. Average weekly values of $\mathrm{pH}$, electrical conductitity (EC) and concentrations of nutrient elements [nitrate-nitrogen $\left(\mathrm{NO}_{3}^{-}-\mathrm{N}\right)$, phosphate-phosphorus $\left(\mathrm{PO}_{4}{ }^{2-}-\mathrm{P}\right)$ and potassium $\left.\left(\mathrm{K}^{+}\right)\right]$in nutrient solution (NS) and runoff $(\mathrm{R})$ of fern leaf lavender grown in 1.5-L (0.40 gal) containers containing peatmoss and perlite 80:20 (by volume). Standard nutrient solutions were amended with different concentrations of sodium chloride to achieve EC levels of the irrigation water of 2.0 ( $\mathrm{T}_{1}$ or control $), 4.5\left(\mathrm{~T}_{2}\right)$, or $7.5\left(\mathrm{~T}_{3}\right) \mathrm{dS} \cdot \mathrm{m}^{-1} \cdot{ }^{\mathrm{z}}$

\begin{tabular}{|c|c|c|c|c|}
\hline \multirow{2}{*}{\multicolumn{2}{|c|}{ Chemical parameters $^{\mathrm{z}}$}} & \multicolumn{3}{|c|}{ Salinity treatments ${ }^{y}$} \\
\hline & & $T_{1}$ & $\mathbf{T}_{2}$ & $\mathbf{T}_{3}$ \\
\hline \multicolumn{5}{|c|}{$($ mean $\pm S D)$} \\
\hline $\mathrm{pH}$ & $\mathrm{R}$ & $6.93 \pm 0.33 \mathrm{aA}$ & $6.90 \pm 0.38 \mathrm{aA}$ & $6.81 \pm 0.35 \mathrm{aA}$ \\
\hline \multirow[t]{2}{*}{$\mathrm{EC}\left(\mathrm{dS} \cdot \mathrm{m}^{-1}\right)$} & NS & $2.00 \pm 0.10 \mathrm{cA}$ & $4.50 \pm 0.19 \mathrm{bB}$ & $7.50 \pm 0.21 \mathrm{aB}$ \\
\hline & $\mathrm{R}$ & $2.15 \pm 0.20 \mathrm{cA}$ & $5.14 \pm 0.21 \mathrm{bA}$ & $8.58 \pm 0.26 \mathrm{aA}$ \\
\hline \multirow[t]{2}{*}{$\mathrm{PO}_{4}{ }^{2-}-\mathrm{P}\left(\mathrm{mg} \cdot \mathrm{L}^{-1}\right)$} & NS & $21.73 \pm 2.31 \mathrm{aA}$ & $21.73 \pm 2.31 \mathrm{aA}$ & $21.73 \pm 2.31 \mathrm{aA}$ \\
\hline & $\mathrm{R}$ & $8.37 \pm 0.93 \mathrm{aB}$ & $8.98 \pm 0.84 \mathrm{aB}$ & $9.00 \pm 0.94 \mathrm{aB}$ \\
\hline \multirow[t]{2}{*}{$\mathrm{K}\left(\mathrm{mg} \cdot \mathrm{L}^{-1}\right)$} & NS & $117.00 \pm 20.67 \mathrm{aA}$ & $117.00 \pm 20.67 \mathrm{aA}$ & $117.00 \pm 20.67 \mathrm{aA}$ \\
\hline & $\mathrm{R}$ & $126.78 \pm 17.33 \mathrm{aA}$ & $125.33 \pm 18.94 \mathrm{aA}$ & $121.57 \pm 19.57 \mathrm{aA}$ \\
\hline
\end{tabular}

${ }^{2} \mathrm{l} \mathrm{dS} \cdot \mathrm{m}^{-1}=1 \mathrm{mmho} / \mathrm{cm}, \mathrm{l} \mathrm{mg} \cdot \mathrm{L}^{-1}=1 \mathrm{ppm}$.

yTreatments were applied from 7 May to 1 July 2010 (8 weeks).

${ }^{x}$ Means within a row with the same lowercase letter are not significantly different at $P<0.05$ (analysis of variance (ANOVA) and least significant difference (LSD) test). Means within a column with the same capital letter are not significantly different at $P<0.05$ (ANOVA and LSD test). 
Table 3. Nutrient balance of fern leaf lavender grown in 1.5-L (0.40 gal) containers containing peatmoss and perlite 80:20 $(\mathrm{v} / \mathrm{v})$ under different salinity levels. Standard nutrient solutions amended with different concentrations of sodium chloride to achieve EC levels of the irrigation water of $2.0\left(\mathrm{~T}_{1}\right.$ or control $), 4.5\left(\mathrm{~T}_{2}\right)$, or $7.5\left(\mathrm{~T}_{3}\right) \mathrm{dS} \cdot \mathrm{m}^{-1} .^{\mathrm{z}}$

\begin{tabular}{|c|c|c|c|c|c|c|c|c|}
\hline \multicolumn{2}{|c|}{$\begin{array}{c}\text { Salinity } \\
\text { treatments }\end{array}$} & $\begin{array}{l}\text { Plant nutrient } \\
\text { uptake }(\mathrm{mg})^{\mathrm{x}}\end{array}$ & $\begin{array}{l}\text { Nutrient applied } \\
\text { per plant (mg) }\end{array}$ & $\begin{array}{l}\text { Nutrient uptake } \\
\text { efficiency }(\%)^{\mathrm{w}}\end{array}$ & $\begin{array}{l}\text { Nutrient runoff } \\
\text { per plant }(\mathrm{mg})^{\mathrm{v}}\end{array}$ & $\begin{array}{c}\text { Nutrient } \\
\text { runoff }(\%)^{u}\end{array}$ & $\begin{array}{c}\text { Unaccounted } \\
\text { nutrient }(\mathrm{mg})^{\mathrm{t}}\end{array}$ & $\begin{array}{l}\text { Unaccounted } \\
\text { loss }(\%)^{s}\end{array}$ \\
\hline \multicolumn{9}{|c|}{$($ mean $\pm S D)$} \\
\hline \multirow[t]{3}{*}{$\mathrm{N}$} & $\mathrm{T}_{1}$ & $108.1 \pm 12.2 \mathrm{a}^{\mathrm{r}}$ & $291.6 \pm 32.3 \mathrm{a}$ & $37.1 \pm 3.1 \mathrm{a}$ & 64. & $22.2 \pm 2.0 \mathrm{c}$ & $118.9 \pm 1$ & 40.7 \\
\hline & $\mathrm{T}_{2}$ & $50.1 \pm 6.2 b$ & $285.7 \pm 29.2 \mathrm{a}$ & $17.5 \pm 1.8 \mathrm{~b}$ & $113.5 \pm 9.7 b$ & $39.7 \pm 4.0 \mathrm{~b}$ & $122.1 \pm 13.2 \mathrm{a}$ & $42.8 \pm 4.1 \mathrm{a}$ \\
\hline & $\mathrm{T}_{3}$ & $25.3 \pm 3.1 c$ & $286.4 \pm 30.1 \mathrm{a}$ & $8.7 \pm 0.9 c$ & $143.9 \pm 11.1 \mathrm{a}$ & $50.4 \pm 4.9 \mathrm{a}$ & $117.2 \pm 11.4 \mathrm{a}$ & $40.9 \pm 3.9 \mathrm{a}$ \\
\hline \multirow[t]{3}{*}{$\mathrm{P}$} & $\mathrm{T}_{1}$ & $15.5 \pm$ & $99.6 \pm 10.1 \mathrm{a}$ & $15.6 \pm 1.3 \mathrm{~b}$ & $0.6 \mathrm{c}$ & $0.5 \mathrm{c}$ & $.1 \mathrm{a}$ & $78.2 \pm 7.5 \mathrm{a}$ \\
\hline & $\mathrm{T}_{2}$ & $37.3 \pm 5.4 \mathrm{a}$ & $97.4 \pm 9.3 \mathrm{a}$ & $38.3 \pm 3.0 \mathrm{a}$ & $10.9 \pm 1.1 \mathrm{~b}$ & $11.2 \pm 1.2 \mathrm{~b}$ & $49.2 \pm 5.1 \mathrm{~b}$ & $50.5 \pm 4.6 b$ \\
\hline & $\mathrm{T}_{3}$ & $40.1 \pm 5.1 \mathrm{a}$ & $96.8 \pm 10.2 \mathrm{a}$ & $41.4 \pm 3.8 \mathrm{a}$ & $14.4 \pm 1.2 \mathrm{a}$ & $14.9 \pm 1.4 \mathrm{a}$ & $42.3 \pm 4.2 b$ & $43.7 \pm 4.7 \mathrm{~b}$ \\
\hline \multirow[t]{3}{*}{$\mathrm{K}$} & $\mathrm{T}_{1}$ & $155.9 \pm 14.1 \mathrm{~b}$ & $458.2 \pm 52.1 \mathrm{a}$ & $34.4 \pm 3.4 b$ & $101.5 \pm 10.1 \mathrm{c}$ & $21.8 \pm 1.8 \mathrm{c}$ & $200.8 \pm 21.1 \mathrm{a}$ & $43.8 \pm 4.0 \mathrm{a}$ \\
\hline & $\mathrm{T}_{2}$ & $194.0 \pm 20.3 \mathrm{a}$ & $462.3 \pm 44.3 \mathrm{a}$ & $41.9 \pm 3.2 \mathrm{a}$ & $165.6 \pm 15.3 \mathrm{~b}$ & $35.3 \pm 3.6 b$ & $102.7 \pm 10.3 b$ & $22.8 \pm 2.5 b$ \\
\hline & $\mathrm{T}_{3}$ & $129.8 \pm 9.1 \mathrm{c}$ & $460.1 \pm 46.1 \mathrm{a}$ & $28.2 \pm 2.6 c$ & $225.2 \pm 19.1 \mathrm{a}$ & $48.9 \pm 4.8 \mathrm{a}$ & $105.1 \pm 10.6 \mathrm{~b}$ & $22.9 \pm 2.3 \mathrm{~b}$ \\
\hline
\end{tabular}

${ }^{\mathrm{z}} 1 \mathrm{dS} \cdot \mathrm{m}^{-1}=1 \mathrm{mmho} / \mathrm{cm}$

yTreatments were applied from 7 May to 1 July 2010 ( 8 weeks); $\mathrm{N}=$ nitrogen, $\mathrm{P}=$ phosphorus, $\mathrm{K}=$ potassium.

xPlant nutrient uptake is the accumulation of each nutrient during the experiment, that is, the difference in nutrient content from initial harvest to final harvest. Initial plants nutrients content gave an average of $75 \mathrm{mg} \mathrm{N}, 9 \mathrm{mg} \mathrm{P}$, and $3 \mathrm{mg} \mathrm{K}$ per plant; $1 \mathrm{mg}=3.5274 \times 10^{-5} \mathrm{oz}$.

"Nutrient uptake efficiency is the percentage of applied nutrient that was taken up after 8 weeks.

"Nutrient runoff per plant is the amount of nutrient leached after 8 weeks and calculated multiplying the concentration of each element in the runoff with their respective volume.

"Nutrient runoff is the percentage of applied nutrient that was leached after 8 weeks.

tUnaccounted nutrient is the difference between nutrient applied and nutrient runoff plus nutrient uptake per plant.

${ }^{\mathrm{s}}$ Unaccounted loss is the percentage of unaccounted nutrient per nutrient applied per plant.

${ }^{\mathrm{r}}$ Means with the same letters within a column are not significantly different at $P<0.05$ (analysis of variance and least significant difference test).

could be related to the rise due to the energy (ATP) required to transport the excess of ions into the vacuoles (Mengel and Kirkby, 2001). Similar results for nitrogen and phosphorus uptake were reported by GarcíaCaparrós et al. (2016), who studied the nutritional behavior of three ornamental potted plants [indian aloe (Aloe vera), flaming katy (Kalanchoe blossfeldiana), and treasure flower (Gazania splendens)] grown under moderate salinity. Plant potassium uptake did not show a clear response to salinity. Conversely with these results, Cassaniti et al. (2009) reported a decrease on potassium uptake in ornamental potted plants such as paper flower (Bougainvillea glabra), juniper-leaf grevillea (Grevillea juniperina), and jelly bush (Leptospermum scoparium) subjected to salinity mainly due to the competition effects between $\mathrm{Na}^{+}$and $\mathrm{K}^{+}$ions which are likely to share the same transport system (Parida and Das, 2005).

The amount of nutrients applied per plant, except for the increase in sodium and chloride of the salinity, were the same in each treatment according to the recommendations given by Jimenez and Caballero (1990) for the growth of ornamental plants under Mediterranean conditions. It should be noted that the $\mathrm{N}$ application rates of ornamental container crops can be 15 times higher than fertilizer rates for agronomic field crops (Chen et al., 2001) and that $\mathrm{P}$ application rates were 100 times higher than plant requirements (Borch et al., 1998; Lin et al., 1996) resulting in low uptake efficiencies and excessive nutrient loss via runoff.

Under the saline conditions reported here, the uptake efficiency of $\mathrm{N}$ and $\mathrm{P}$ showed different trends. The nitrogen uptake efficiency (NUE) declined significantly with saline stress (28\% lower compared with the control), whereas phosphorus uptake efficiency (PUE) increased with higher EC $\left(4.5\right.$ and $\left.7.5 \mathrm{dS} \cdot \mathrm{m}^{-1}\right)(23 \%$ and $26 \%$, respectively, compared with the control). Similarly, Ristvey et al. (2007) also reported an increase in NUE (from $12 \%$ to $38 \%$ ) and PUE (from $11 \%$ to $50 \%$ ) by reducing the $\mathrm{N}$ and $\mathrm{P}$ fertilization to match plant growth requirements of azalea $\left(R h o^{-}\right.$ dodendron) plants. The values of NUE in our experiment may be overestimated as a result of available nutrients in the soilless potting substrate as reported by Sandrock et al. (2005) who suggest that $\mathrm{N}$ may be mineralized in soilless potting media. Similar findings were reported by other researchers in soilless media, who reported a high percentage of $\mathrm{N}$ immobilized and denitrified by microorganisms (Cabrera, 2003; Scagel, 2003 ) or volatilized (Rathier and Frink, 1989). On the other hand, $\mathrm{K}^{+}$ uptake efficiency (KUE) did not show a clear response to salinity as happens with the plant $\mathrm{K}^{+}$uptake discussed above. These results disagree with Scagel et al. (2011) who reported an increase of KUE in different azalea cultivars with two different rates of $\mathrm{N}$ fertilizers.

Salt stress increased the nutrient runoff per plant and consequently the percentage of runoff compared with the control plants. The increase of $\mathrm{N}$, $\mathrm{P}$, and $\mathrm{K}$ runoff can be because the organic potting substrates have little $\mathrm{NO}_{3}{ }^{-}-\mathrm{N}$ and $\mathrm{PO}_{4}{ }^{2-}-\mathrm{P}$ retention qualities and very poor cation exchange capacities, especially those that are pine bark or peat based (Marconi and Nelson, 1984). The values of runoff per plant in our experiment ranging for $\mathrm{N}$ (65-144 mg), $\mathrm{P}$ (6-14 $\mathrm{mg})$, and $\mathrm{K}(102-225 \mathrm{mg})$, whereas Ristvey et al. (2007) reported values of runoff for $\mathrm{N}(4-152 \mathrm{mg})$ and $\mathrm{P}(2-$ $16 \mathrm{mg}$ ) in an experiment with different fertilizer rates being necessary to point out that these results are not directly comparable to ours due to container size and spacing differences.

The increase in runoff consequently assumed that the nutrient runoff expressed in percentage increase compared with the control plants $(28 \%, 9 \%$, and $27 \%$ for $\mathrm{N}, \mathrm{P}$, and $\mathrm{K}$, respectively). These runoff percentages were lower compared with the data reported by other 
researchers. Hershey and Paul (1982) reported $12 \%$ to $48 \%$ of $\mathrm{N}$ runoff for potted chrysanthemums irrigated with $\mathrm{N}$ solutions of $100-300 \mathrm{mg} \cdot \mathrm{L}^{-1}$, Cabrera (2003) reported $16 \%$ to $58 \%$ of runoff in a $\mathrm{N}$ balance of two container-grown ornamental plants irrigated with different $\mathrm{N}$ concentrations, Warsaw et al. (2009) reported in container-grown ornamental plants that compared with their control, $\mathrm{N}$ loading in runoff was reduced, on average, $38 \%$ and $59 \%$ with their $100 \%$ and $75 \%$ of daily water use (DWU) application rates. Likewise, $P$ runoff in their $100 \%$ and $75 \%$ DWU treatments were $46 \%$ and $74 \%$, respectively, lower than their control. Similarly, Pershey and Cregg (2015) also reported in four conifers (Pinophyta) grown in containers that the control of the irrigation based on DWU reduced runoff $\mathrm{NO}_{3}{ }^{-} \mathrm{N}$ by $36 \%$ and $67 \%$ and $\mathrm{PO}_{4}{ }^{3-}-\mathrm{P}$ runoff by $38 \%$ and $57 \%$ with $100 \%$ and $75 \%$ DWU irrigation applications, respectively. A final major observation was that to complete the nutrient balance, the total nutrients applied could not be accounted for at the end of the experiment as proposed Ristvey et al. (2007) ( $41 \%$ to $43 \%$ in N, $44 \%$ to $78 \%$ in $\mathrm{P}$, and $23 \%$ to $44 \%$ in $\mathrm{K}$ ).

\section{Conclusions}

Results indicate that the production of fern leaf lavender in containers with increasing $\mathrm{NaCl}$ in the nutrient solution did not reduce either the plant DW or WUE, but based on nutrient balance, plant nutrient uptake was affected (NUE declined 28\% and PUE increased 26\%; whereas, KUE did not show a clear trend). In addition, the increase of $\mathrm{NaCl}$ in the nutrient solution increased the volume of water leached per plant and consequently, increased the nutrient runoff per plant and the nutrient runoff expressed in percentage $(28 \% \mathrm{~N}, 9 \% \mathrm{P}$, and $27 \% \mathrm{~K})$ which would lead us to conclude that it would be not advisable to grow this species with high EC water from an environmental point of view.

\section{Literature cited}

Abdelgadir, E.M., M. Oka, and H. Fujiyama. 2005. Characteristics of nitrate uptake by plants under salinity. J. Plant Nutr. 28:33-46.

Alvarez, S., M.J. Gómez-Bellot, M. Castillo, S. Bañón, and M.J. Sánchez-Blanco. 2012.
Osmotic and saline effect on growth, water relations, and ion uptake and translocation in Phlomis purpurea plants. Environ. Expt. Bot. 78:138-145.

Alvarez, S. and M.J. Sánchez-Blanco. 2014. Long-term effect of salinity on plant quality, water relations, photosynthetic parameters and ion distribution in Callistemon citrinus. Plant Biol. 16:757764.

Borch, K., K.M. Brown, and J.P. Lynch. 1998. Improvement of bedding plant quality and stress resistance with low phosphorus. HortTechnology 8:575579.

Brady, N.C. and R.R. Weil. 1999. The nature and properties of soils. 12th ed. Prentice Hall, Upper Saddle River, NJ.

Cabrera, R. 2003. Nitrogen balance for two container-grown woody ornamental plants. Sci. Hort. 97:297-308.

Cassaniti, C., C. Leonardi, and T.J. Flowers. 2009. The effect of sodium chloride on ornamental shrubs. Sci. Hort. 122:586-593.

Cassaniti, C., D. Romano, M.E.C.M. Hop, and T.J. Flowers. 2013. Growing floricultural crops with brackish water. Environ. Expt. Bot. 92:165-175.

Chavez, W., A. Di Benedetto, G. Civeira, and R. Lavado. 2008. Alternative soilless media for growing Petunia bybrida and Impatiens walleriana: Physical behavior, effect of fertilization and nitrate losses. Bioresour. Technol. 99:8082-8087.

Chen, J., Y. Huang, and R.D. Caldwell. 2001. Best management practices for minimizing nitrate leaching from containergrown nurseries. Proc. Scientific World 1:96-102.

Contreras, J.I. 2014. Optimización de las estrategias de fertirrigación de cultivos hortícolas en invernadero utilizando aguas de baja calidad (agua salina y agua regenerada) en condiciones del litoral de Andalucía. PhD Diss., Univ. Almeria, Almeria, Spain.

Csáky, A.G. and M.A. Martínez-Grau. 1998. Técnicas experimentales en síntesis orgánica. Editorial Síntesis, Madrid, Spain.

Dana, E.D., S. Vivas, and J.F. Mota. 2002. Urban vegetation of Almerìa City: A contribution to urban ecology in Spain. Lands. Urban Planning 59:203-216.

Daniele, L., A. Vallejos, F. Sola, M. Corbella, and A. Pulido-Bosch. 2011. Hydrogeochemical processes in the vicinity of a desalination plant (Cabo de Gata, SE Spain). Desalination 277:338-347.

Dudley, L.M., A. Ben-Gal, and U. Shani. 2008. Influence of plant, soil, and water on the leaching fraction. Vadose Zone J. 7:420-425.

European Environmental Agency (EEA). 2014. European and national drinking water quality standards. 11 Oct. 2016. <http://www.fsai.ie/uploadedFiles/ Legislation/Food_Legisation_Links / Water/SI122_2014.pdf>.

García-Caparrós, P., A. Llanderal, M. Pestana, P. Correia, and M.T. Lao. 2016. Tolerance mechanisms of three potted ornamental plants grown under moderate salinity. Sci. Hort. 201:84-91.

Hanson, B.R., S.R. Grattan, and A. Fulton. 2006. Agricultural salinity and drainage. University of California, Davis, CA.

Hershey, D.R. and J.L. Paul. 1982. Leaching-losses of nitrogen from pot chrysanthemums with controlled-release or liquid fertilization. Sci. Hort. 17:145152.

Hogue, E., G.E. Wilcow, and D.J. Cantliffe. 1970. Effect of soil P on phosphate fraction in tomato leaves. J. Amer. Soc. Hort. Sci. 95:174-176.

Howarth, R.W. and R. Marino. 2006. Nitrogen as the limiting nutrient for eutrophication in coastal marine ecosystems: Evolving views over three decades. Limnol. Oceanogr. 51:364-376.

Jimenez, R.M. and M.R. Caballero. 1990. El cultivo industrial de plantas en maceta. Editorial Horticultura Sociedad Limitada, Barcelona, Spain.

Krom, M.D. 1980. Spectrophotometric determination of ammonia: Study of a modified Berthelot reaction using salicylate and dicholoroisocyanurate. Analyst (Lond.) 105:305-316.

Lachica, M., A. Aguilar, and J. Yanez. 1973. Análisis foliar: Métodos utilizados en la Estación Experimental del Zaidin. Anales de Edafología y Agrobiología 32:1033-1047.

Lin, Y.L., E.J. Holcomb, and J.P. Lynch. 1996. Marigold growth and phosphorus leaching in a soilless medium amended with phosphorus charged alumina. HortScience 31:94-98.

Lütken, H., J.L. Clarke, and R. Müller. 2012. Genetic engineering and sustainable production of ornamentals: Current status and future directions. Plant Cell Rpt. 31:1141-1157.

Marconi, D.J. and P.V. Nelson. 1984. Leaching of applied phosphorus in container media. Sci. Hort. 22:275-285.

Mengel, K. and E.A. Kirkby. 2001. Principles of plant nutrition. Kluwer Academic Publ., Dordrecht, The Netherlands. 
Munns, R. and M. Tester. 2008. Mechanisms of salinity tolerance. Annu. Rev. Plant Biol. 59:651-681.

Parida, A.K. and A.B. Das. 2005. Salt tolerance and salinity effects on plants: A review. Ecotoxicol. Environ. Saf. 60:324349.

Pershey, N.A. and B.M. Cregg. 2015. Irrigating based on daily water use reduces nursery runoff volume and nutrient load without reducing growth of four conifers. HortScience 50:1553-1561.

Pignatti, S. 1982. Flora d'Italia. Editoriale Edagricoltore, Bologna, Italy.

Pinto, J.R., R.A. Chandler, and R.K. Dumroese. 2008. Growth, nitrogen use efficiency, and leachate comparison of subirrigated and overhead irrigated pale purple coneflower seedlings. HortScience 43:897-901.
Rathier, T.M. and C.R. Frink. 1989. Nitrate in runoff water from container grown juniper and alberta spruce under different irrigation and $\mathrm{N}$ fertilization regimes. J. Environ. Hort. 7:32-35.

Ristvey, A.G., J.D. Lea-Cox, and D.S. Ross. 2007. Nitrogen and phosphorus uptake efficiency and partitioning of container-grown azalea during spring growth. J. Amer. Soc. Hort. Sci. 132:563571.

Sandrock, D.R., T.L. Righetti, and A.N. Azarenko. 2005. Isotopic and nonisotopic estimation of nitrogen uptake efficiency in container grown woody ornamentals. HortScience 40:665-669.

Scagel, C.F. 2003. Growth and nutrient use of ericaceous plants grown in media amended with sphagnum moss peat or coir dust. HortScience 38:46-54.
Scagel, C.F., G. Bi, L.H. Fuchigami, and R.P. Regan. 2011. Nutrient uptake and loss by container-grown deciduous and evergreen rhododendron nursery plants. HortScience 46:296-305.

U.S. Environmental Protection Agency. 2010. Drinking water contaminants: National primary drinking water regulations. 6 Dec. 2010. <http://water.epa.gov/ drink/contaminants/index.cfm $>$.

Warsaw, A.L., R.T. Fernandez, B.M. Cregg, and J.A. Andresen. 2009. Containergrown ornamental plant growth and water runoff nutrient content and volume under four irrigation treatments. HortScience 44:1573-1580.

Wilson, P.C. and J.P. Albano. 2011. Impact of fertigation versus controlledrelease fertilizer formulations on nitrate concentrations in nursery drainage water. Hort Technology 21:176-180. 